\title{
PKM Pelatihan Promosi Penjualan pada Pedagang di Tonggimoncong
}

\author{
Mustari $^{1}$, Ilham Thaef ${ }^{2}$, M.Ihsan Said Ahmad ${ }^{3}$ \\ 1,2,3 Fakultas Ekonomi, Universitas Negeri Makassar Makassar
}

\begin{abstract}
The purpose of the training is to provide insight, knowledge, and practice to merchants in Tinggimoncong, Gowa Regency as participants in sales promotion training, so that they can develop their own methods or methods in sales promotion and can run their business according to the plans that have been drawn up which lead to achieving goals. . The benefit of the training activity is that participants can implement sales promotions in the business according to their wishes and obtain the merchant's business performance as expected.This service activity was attended by 20 traders in Tinggi Moncong, Gowa Regency. There were several participants who previously registered themselves to take part in this activity, but the participants were unable to attend at the time of implementing the activity. The training participants were very enthusiastic about participating in this activity, as evidenced by their timely arrival. Enthusiasm was also seen in listening to the explanations from the speakers and the many questions asked about the material given. Although at the end of the activity session a special time was provided for question and answer, some participants also asked questions in the middle of the material given. The implementation of sales promotion training in order to increase sales of merchants in Tinggi Moncong, Gowa Regency can increase their sales results in the future. For traders, using and implementing effective sales promotion methods and methods has implications for their sales results. And become part of the prospect as a necessity in the interaction. This has become a positive value for traders in doing business because they are able to make friends with many people and try to build networks in their trading business. This is a strength as well as an opportunity that can be reached and useful for introducing and offering products to prospective buyers which have implications for increasing their merchandise.
\end{abstract}

Keywords: Training, Sales Promotion, Traders

\section{PENDAHULUAN}

Perkembangan ekonomi yang sangat cepat dan dinamis yang terjadi dewasa ini mengakibatkan muncul pesaing dari berbagai jenis usaha baik, usaha yang bergerak dalam bidang perdagangan, jasa, maupun usaha dalam bidang produksi. Hal tersebut mengakibatkan produsen atau pemilik usaha harus lebih cermat dan selektif dalam memilih metode yang digunakan dalam menyalurkan produknya. Hadirnya pesaing tersebut maka terjadi persaingan yang ketat antara usaha, baik yang dijalankan secara perseroan maupun perseorangan. Sehingga dituntut untuk memiliki strategi dan cara-cara dalam mengatasi keadaan tersebut, agar tujuan usaha yang telah ditetapkan dapat tercapai.

Menghadapi masalah persaingan tersebut, maka perusahaan harus melihat dan meningkatkan strategi pemasarannya terutama dalam hal mengkomuniasikan produk yang akan ditawarkan kepada konsumen. Cara atau metode tersebu merupakan salah satu unsure atau variable dalam aktivitas pemasaran.

Menurut Philip Kotler (2010(), menyatakan bahwa pemasaran adalah proses perencanaan dan pelaksanaan dari perwujudan, pemberian harga, promosi dan distribusi dari barang-barang, jasa dan gagasan untuk menciptakan pertukaran dengan kelompok sasaran yang memenuhi tujuan pelanggan dan organisasi.

Menurut Stanton (2001), definisi pemasaran adalah suatu sistem keseluruhan dari kegiatankegiatan bisnis yang ditujukan untuk merencanakan, menentukan harga, mempromosikan dan mendistribusikan barang atau 
jasa yang memuaskan kebutuhan kepada para pembeli yang ada.

Dewasa ini pemasaran tidak hanya untuk mengembangkan produk yang berkualitas, menarik, dan terjagkau oleh konsumen, namun pemasaran juga suatu kegiatan yang memegang peranan penting dalam meningkatkan hasil penjualan perusahaan melalui kegiatan promosi.Promosi merupakan salah satu upaya atau kegiatan untuk mengenalkan barang dan jasa hasil produksi kepada konsumen. Dan dalam pelaksanaan promosi tentu diperlukan biaya promosi yang cukup besar sesuai dengan apa yang dipromosikan, artinya kegiatan promosi yang dilakukan diharapkan akan meningkatkan omzet serta dapat menambah pelanggan oleh perusahaan tersebut.

Menurut Sutojo (2009 : 265), promosi adalah kegiatan yang dilakukan untuk memberitahu pembeli tentang keberadaan produk di pasar atau kebijaksanaan pemasaran tertentu yang baru ditetapkan perusahaan misalnya, pemberian bonus pembelian atau potongan harga.Promosi penjualan adalah bagian penting dari strategi komunikasi pemasaran perusahaan, sejalan dengan periklanan, humas dan penjualan personal. Pada intinya, promosi penjualan merupakan aktivitas pemasaran yang mengusulkan nilai tambah dari suatu produk (untuk mendapatkan lebih dari sekedar yang ada dari nilai produk) dalam jangka waktu tertentu guna mendorong pembelian konsumen, efektivitas penjualan, atau mendorong upaya yang dilakukan oleh tenaga penjual. Dari pengertian tersebut, sasaran promosi penjualan dapat ditunjukan kepada konsumen, pedagang perantara seperti kepada tenaga penjualan. Promosi penjualan berangkat dari premis bahwa setiap merek atau jasa memiliki nilai dan harga tertentu, atau harga "regular", atau beberapa nilai referen tertentu. Promosi penjualan dipercaya mampu mengubah nilai harga yang telah diterima tersebut dengan menaikkan nilai dan/atau menurunkan harga. Contoh promosi penjualan yang dikenal konsumen misalnya: kontes, bonus, diskon jangka pendek, bonus pada barang, rabat, kupon, uji coba gratis, demonstrasi dan system akumulasi nilai/point. (Agus Hermawan, 2012 : 128)

Menurut (Blattberg dan Neslin, 1995) dalam buku Komunikasi Pemasaran, Promosi penjualan merupakan orientasi tindakan pemasar yang tujuannya diharapkan berdampak langsung terhadap perilaku tindakan konsumen untuk membeli.

Tujuan pelatihan untuk memberikan bekal wawasan, pengetahuan, dan praktik kepada pedagang di Tinggimoncong Kabupaten Gowa sebagai peserta dalam pelatihan promosi penjualan, sehingga mereka dapat menyusun sendiri cara atau metode dalam promosi penjualan dan dapat menjalankan usahanya sesuai dengan rencana yang telah disusun yang mengerah pada pencapaian tujuan.

Manfaat kegiatan pelatihan adalah peserta dapat menrapkan promosi penjualan dalam usaha yang sesuai dengan keinginan mereka dan memperoleh kinerja usaha pedagang yang sesuai dengan yang diharapkan.

\section{METODE YANG DIGUNAKAN}

\section{Permasalahan Mitra}

Program Program Kemitraan Masyarakat (PKM) akan dilaksanakan untuk mengatasi masalah - masalah yang muncul dalam masyarakat berkaitan dengan promosi penjualan suatu produk. Secara spesifik masalah yang akan diangkat meliputi:

a. Pentingnya promosi penjualan dalam rangka melakukan usaha bagi pedagang sebagai salah satu sumber daya yang mampu melaksanakan promosi penjualan.

b. Semakin ketatnya persaingan usaha membuat pedagang harus mampu memanfaatkan promosi sebagai sarana informasi dalam menjual produk. Solusi yang Ditawarkan

Sebagai pedagang berarti melalkukan cirri atau karakteristik menjadi seorang entrepreneur sehingga banyak lapangan kerja yang tercipta dan dapat mengurangi jumlah pengangguran.

Dalam mata kuliah manajemen pemasaran, pengantar bisnis dan kewirausahaan, diberikan materi mengenai cara untuk memperkenalkan 
suatu dan mempromosikan usaha tersebut. Salah satu bagian penting dalam usaha tersebut adalah dapat mempromosikan atau memperkenalkan produk. Promosi Penjualan merupkan kunci kesuksesan usaha. Pemasaran yang selama ini banyak dilakukan adalah pemasaran secara konvensional, misalnya melalui pembagian dan penyebaran brosur, iklan, spanduk, dan menawarkan langsung ke calon pembeli. Cara yang dilakukan seperti ini tidak akan mencapai target pasar yang luas dan produk pun hanya dikenali oleh sebagian pembeli saja.

Sebagai pedagang bisa melakukan rencana bisnis untuk menyelesaikan masalah dalam membangun dan mengembangkan usaha, terutama dalam berwirausaha. Media online, seperti facebook dan twitter sudah tidak asing lagi bagi masyarakat, dan hal ini bisa dimanfaatkan untuk melakukan pemsaran secara online. Dalam memanfaatkan penggunaan media online sebagai sarana untuk memasarkan produk, seorang pedagan perlu mengehui tata cara penggunaan dan pemanfaatannya, agar tujuan pemasaran dapat tercapai.

Bagi kalangan pedagang, menggunakan dan menjadi bagian dari komunitas dalam media online sudah menjadi kebutuhan dalam bersosialisasi. Hal ini sudah menjadi poin positif bagi pedagang karena mampu menjaring pertemanan dengan banyak orang dan berusaha membangun relasi usaha dengannya. Hal ini bisa dimanfaatkan juga untuk mengenalkan dan menawarkan produk usaha yang akan dijual. Namun, masih terbatasnya pedagang yang bisa mengelola media online-nya sebagai sarana untuk pemasaran produk, sehingga pedagang di Timggimoncing Kabupaten Gowa perlu diberikan pelatihan mengenai cara-cara mempromosikan produk yang ditawarkan kepada konsumen.

\section{Luaran}

Masalah yang dihadapi dalam menjalankan suatu usaha adalah pemanfaatan media promosi. Saat ini usaha banyak dilakukan dengan pembagian dan penyebaran brosur, iklan, spanduk, dan menawarkan langsung ke calon pembeli. Hal ini membuat ruang lingkup pasar menjadi terbatas dan tidak berkembang. Pedagang sebagai salah satu sumber daya yang diharapkan dapat mengatasi permasalahan tersebut. Salah satunya adalah dengan pemanfaatan media online untuk melakukan promosi penjualan suatu produk. Berdasarkan uraian permasalahan yang dihadapi, maka target dalam kegiatan PKM ini adalah pedagang di Tinggimoncong Kabupaten Gowa mampu memberikan konstribusi dalam menyelesaikan masalah pemasaran khususnya promosi penjualan. Dengan optimalnya pemasaran yang dilakukan, maka usaha akan berjalan dengan lancar dan mendapatkan keuntungan yang ditargetkan, sehingga hal ini bisa mengembangkan jiwa usaha pedagang yang inovatif dan kreatif dalam berusaha atau berbisnis.

Ada beberapa luaran yang akan dicapai dalam kegiatan PKM ini, diantaranya:

a. Ringkasan pelaksanaan promosi penjualan

b. Media promosi

c. Strategi promosi

d. Produk dan jasa

e. Strategi pemasaran

f. Analisis Pesaing

g. Ringkasan mitra

h. Rencana operasional

i. Data finansial

j. Jadwal operasional

k. Sertifikat pelatihan

\section{Pelaksanaan Kegiatan}

Melaksanakan pelatihan kepada pedagang di Tinggimoncong Kabupaten Gowa dengan menyampaikan surat tugas/izin lembaga pengabdian kepada masyarakat dari perguruan tinggi Universitas Negeri Makassar. Kami diterima untuk melaksanakan pelatihan pada Hari Sabtu dan Minggu Tanggal 3 dan 4 Oktober 2029. Adapun pelaksanaan kegiatan yang adalah sebagai berikut:

a. Mengkoordinir pedagang di Tinggimoncing Kabupaten Gowa yang tergabung dalam pelatihan promosi penjualan.

b. Menyiapkan sarana pelaksanaan pelatihan untuk memberikan materi berupa teori dengan menggunakan metode ceramah. Adapun yang 
dipersiapkan antara lain: papan white board untuk menulis dalam memberikan materi pelatihan, spidol untuk menulis dan LCD.

\section{PELAKSANAAN DAN HASIL KEGIATAN}

Pelaksanaan kegiatan pengabdian kepada masyarakat dengan judul "Pelatihan Promosi Penjualan Bagi Pedagang di Tinggi Moncong Kabupaten Gowa telah selesai dilaksanakan. Berikut merupakan hasil yang telah dicapai dalam kegiatan pengabdian ini.

Pembentukan panitia kegiatan membuat struktur organisasi kepanitiaan dan pembagian tugas agar kegiatan dapat berjalan dengan lancar Susunan panitia kegiatan yang terdiri dari tim pelaksana dan tim teknis yang berasal dari tim pegabdi secara terpadu dari Program Studi Pendidikan Ekonomi UNM yang mengikuti pelatihan

Evaluasi kegiatan Mengetahui hal-hal yang sudah baik dan yang belum berjalan dengan baik Saran untuk perbaikan kegiatan selanjutnya yang serupa Pembuatan laporan akhir Melaporkan rangkaian kegiatan yang telah dilakukan Kegiatan pengabdian ini telah dilaksanakan selama 2 (dua) hari Kegiatan pengabdian ini diisi dengan materi mengenai promosi penjualan dalam usaha pedagang.

Kegiatan pengabdian ini diikuti oleh pedagang di Tinggi Moncong Kabupaten Gowa yang berjumlah 20 orang. Ada beberapa peserta yang sebelumnya mendaftarkan diri untuk mengikuti kegiatan ini, namun para peserta berhalangan hadir pada waktu pelaksanaana kegiatan.

Peserta pelatihan sangat antusias untuk mengikuti kegiatan ini, dibuktikan dengan kedatangan mereka yang tepat waktu. Antusiasme juga terlihat dalam mendengarkan penjelasan dari pemateri dan banyaknya pertanyaan yang diajukan seputar materi yang diberikan. Walaupun diakhir sesi kegiatan disediakan waktu khusus untuk tanya jawab, namun beberapa peserta juga mengajukan pertanyaan disela-sela materi diberikan.

Sebelum memulai penyampaian materi, pemateri pertama yaitu Dr. Mustari, S.E.,M.Si. terlebih dahulu memberikan pertanyaan sebagari pre-test. Pertanyaan pre-test diberikan untuk mengetahui sejauh mana pengetahuan dan pemahaman peserta tentang promosi penjualan. Pertanyaan yang diberikan meliputi apakah peserta sudah memiliki usaha perdagangan, bagaimana cara memperkenalkan produk, bagaimana mempromosikan usaha yang dijalankan, dan media apa yang efektif untuk memperkenalkan dan memasarkan produk bisnis yang dijalankan. Jawaban pre-test dari peserta rata-rata belum ada yang menjalankan bisnis.

Hal inilah yang melatar belakangi para peserta untuk mengikuti kegiatan pelatihan ini Materi kedua dan ketiga masing - masing disampaikan oleh Prof. Dr. Ir. Ilham Thaeif, M.M. dan Dr. M. Ihsan Said Ahmad, S.E.,M.Si. materi yang diberikan berkaitan dengan promosi penjualan. Ketertarikan peserta sudah mulai terlihat dengan adanya beberapa pertanyaan yang ditujukan pada pemateri berkaitan dengan promosi penjualan. Peserta juga memberikan contoh-contoh promosi yang bisa diterapkan untuk usaha atau menjual. Pemateri juga memberikan contoh promosi penjualan dan cara melaksanakannya..

Materi yang berkaitan dengan promosi penjualan sebagai sarana dalam usaha khususnya perdagangan. Sesi ketiga diawali dengan melakukan review terhadap dua materi yang sebelumnya telah diberikan. Ternyata para peserta masih bisa mengingat tentang hal-hal penting yang dapat diambil dari dua materi sebelumnya. Dalam materi ketiga disampaikan metode dan cara promosi penjualan dalam usaha yang bergerak dalam perdaganagn. Peserta juga memberikan beberapa contoh ide dari tema yang bisa dilakukan untuk usaha bagi pedagang di Tinggimoncong Kabupaten Gowa..

Sesi terakhir kegiatan pengabdian ini adalah sesi tanya jawab. Disini para peserta secara aktif mengajukan pertanyaan yang berkaitan dengan promosi penjualan, terutama mengenai media, dan cara penggunaannya. Beberapa pertanyaan yang diajukan misalanya kelebihan dan kelemahan promosi penjualan dalam melakukan usaha bagi pedagang, kendala dalam melakukan promosi 
penjualan, dan bagaimana cara menerapakan media promosi yang digunakan. Setalah Tanya jawab selesai, pemateri memberikan post-test, untuk mengukur tingkat penerimaan dan pemahaman peserta selama mengikuti kegiatan pelatihan ini.

Hasil post-test, peserta sudah memiliki cara mempromosikan produknya yang bisa dijalankan sesuai yang direncanakan sebelumnya, serta peserta juga mengetahui metode dan cara menerapkan media promosi untuk usaha menjual produk.

Faktor yang mendorong kegiatan pelatihan promosi penjualan bagi pedagang di Tinggimoncong Kabupaten Gowa sebagai berikut:

1. Sebagian pedagang sebagai peserta pelatihan belum bisa menerapkan promosi penjualan secara efektif, sehingga dengan adanya kegiatan pelatihan ini mereka mempunyai cara dan metode dalam mempromosikan jualannya masing-masing.

2. Kegiatan mempromosikan penjualan bagi pedagang dalam rangka menjual barang dagangannya.

3. Memanfaatkan media promosi bagi pedagang dalam menjual barang dagangannya sehimgga dapat meningkatkan penjualannya.

Faktor yang menghambat kegiatan pelatihan promosi penjualan ini bagi pedagang sebagai berikut:

1. Tidak tersedianya ruangan atau tempat khusus untuk pelatihan, sehingga tempat pelatihan cukup sederhana..

2. Pedagang kurang berminat mengikuti kegiatan pelatihan promosi penjualan karena terbiasa dengan penjualan secara langsung.

\section{KESIMPULAN}

Pelaksanaan pelatihan promosi penjualan dalam rangka meningkatkan penjualan pedagang di Tinggi Moncong Kabupaten Gowa dapat meningkatkan hasil jualannya di masa yang akan datang.. Bagi pedagang, menggunakan dan menerapkan metode dan cara promosi penjualan secara efektif yang berimplikasi pada hasil julannya. Dan menjadi bagian dari calon pelanggan sebagai kebutuhan dalam berinterkasi. Hal ini sudah menjadi nilai positif bagi pedagang dalam berusaha karena mampu menjaring pertemanan dengan banyak orang dan berusaha membangun jaringan dalam usaha dagangannya. Hal ini menjadi kekuatan sekaligus peluang yang dapat diraih dan bermanfaat untuk memperkenalkan dan menawarkan produk kepada calon pembeli yang berimplikasi pada peningkatan barang dagangannya.

Di masa yang akan datang, diperlukan suatu pelatihan yang lebih mendalam untuk meningkatkan peran aktif masyarakat sebagai sasaran dalam ikut mengatasi masalah-masalah yang muncul dalam dunia usaha utamanya yang berkaitan dengan pemasaran produk yang salah satu dimensinya yaitu promosi penjualan produk. Pelatihan yang dapat dilaksanakan seperti pelatihan tentang kewirausahaan. Sehingga akan semakin memaksimalkan suatu usaha dan dapat bersaing dalam menghadapi masa yang semakin kompetitif.

\section{DAFTAR PUSTAKA}

Alma. Buchari. 2004. Manajeman Pemasran Dan Pemasaran Jasa. Cetakan Ke Enam. : Cv. Alfabeta

Duncan, Tom, 2005, Principle Of Advertising and $I M C$, International Edition, Edisi Kedua, McGrawHill, New York.

Duncan, Tom. (2002). (MC: Using Advertising \& Promotion to Build Brands. New. York: McGraw-Hill Higher Companies

Hermawan Agus. 2012. Komunikasi Pemasaran. Malang: PT. Gelora Aksara Pratama.

Gitusudarmo. H. Indriyo M. Com (Hens), 2003. Manajemen Pemasaran. Yogyakarta : Penerbit BPFE-Yogyakarta.

Kotler Philip \& A.B. Susanto. 2000. Manajemen Pemasaran Indonesia. Jakarta: Salemba Empat.

Kotler \& Armstrong. 2001. Prinsip-prinsip Pemasaran. Jakarta: PT. Gelora Aksara Pratama.

Kotler. 2002. Manajemen Pemasaran. Jilid 1, Edisi Kesepulu. Jakarta : PT. Prenhallindo.

Mursid. 2014. Manajemen Pemasaran. Jakarta: PT. Bumi Aksara Prawirosentono Suyadi. 2001. Manajemen Mutu Terpadu. Jakarta: PT. Bumi Aksara 
182 Jurnal Dedikasi, Vol. 22, No. 2, 2020 (177-182)

Sutojo. 2009. Manajemen Pemasaran, edisi kedua, Stanton, William J. 2001. Prinsip Pemasaran. Jakarta: Damar Mulia Pustaka

Jakarta : Erlangga 